DOI: $10.19195 / 2300-7729.36 .11$

\title{
Czytelnictwo więźniów w Zakładzie Karnym w Rawiczu
}

\section{Wstęp}

Biblioteki więzienne stanowią istotną część więziennego środowiska. Pełnią funkcję edukacyjną, rekreacyjną, rehabilitacyjną i pozwalają konstruktywnie spędzać czas. W więzieniu skazani są ściśle pilnowani, monitorowani, zostaje im narzucony określony plan dnia oraz zasady, do których muszą się dostosować. Biblioteka jest miejscem, w którym więźniowie sami dokonują wyborów i angażują się w zajęcia, które ich interesują. Jest „oknem na świat zewnętrzny”, dostarcza aktualnych informacji o życiu poza więzieniem oraz zapewnia dostęp do potrzebnej wiedzy, która przygotuje osadzonych do powrotu do społeczeństwa i pomoże rozwiązać ewentualne problemy. Biblioteka więzienna powinna spełniać podobne zadania, jak biblioteka publiczna. W większości krajów do zakładów karnych trafiają ludzie niewykształceni, niewywodzący się ze środowisk, w których czytanie to popularna rozrywka. Znacząca liczba więźniów ma niski poziom piśmienności i niewielkie umiejętności niezbędne przy zdobywaniu pracy. Biblioteka powinna umożliwiać rozwijanie umiejętności czytelniczych oraz promować naukę i kulturę. Wzrost czytelnictwa wśród więźniów zależy od wykwalifikowanych pracowników, księgozbioru, który powinien zaspokajać potrzeby użytkowników oraz przestrzeni, która powinna zachęcić do korzystania z biblioteki ${ }^{1}$.

\section{Rozwój i działalność bibliotek więziennych w Polsce}

Książki od dawna były wykorzystywane w zakładach karnych do rehabilitacji moralnej więźniów i do resocjalizacji poprzez naukę, pracę i religię. Już w powstających od II połowy XVI wieku domach poprawy pojawiały się niewielkie zbiory

${ }^{1}$ V. Lehmann, J. Locke, IFLA: Guidelines for library services to prisoners, The Hague 2005, s. 4-5, http://www.ifla.org/files/assets/hq/publications/professional-report/92.pdf [dostęp: 26.05.2015]. 
książek do dyspozycji skazanych i ich opiekunów. Na początku gromadzono wyłącznie literaturę religijną, a Biblia była podstawową lekturą więźniów ${ }^{2}$. W późniejszych latach coraz więcej zakładów karnych zaczęło organizować biblioteki, których zasoby stawały się coraz większe i różnorodniejsze. Powołano do życia Centralną Bibliotekę Więzienną mającą dbać o rozwój czytelnictwa wśród skazanych, podnosić jakość prac bibliotekarskich w więzieniach oraz ujednolicić zasady prowadzenia biblioteki więziennej ${ }^{3}$. Po zakończeniu II wojny światowej księgozbiory w więzieniach trzeba było tworzyć od podstaw. Ustalono ogólne zasady prowadzenia bibliotek więziennych, do których funkcjonowania zobowiązano wszystkie zakłady karne. Instrukcja Departamentu Więziennictwa określiła zasady korzystania z ich zbiorów, według których więźniowie nie mieli wolnego dostępu do księgozbioru, otrzymywali listę publikacji do celi i tak wybierali interesującą ich lekturę, którą później dostarczał im funkcjonariusz odpowiedzialny za bibliotekę. W 1955 roku opracowano Regulamin Więzienny uprawniający skazanych do posiadania książek i prasy w celi oraz do udziału w wydarzeniach kulturalno-oświatowych odbywających się w bibliotece. Zaczęto dostrzegać, że obok nauki i pracy zajęcia kulturalne są ważnym czynnikiem resocjalizacji, kształtującym świadomość obywatelską i społeczną, rozwijającym zdolności i zainteresowania skazanych oraz podnoszącym ich kwalifikacje zawodowe ${ }^{4}$. Jednak dopiero po roku 1989 zmieniono całkowicie charakter więziennictwa z modelu represyjnego na resocjalizacyjny. Celem odbywania kary pozbawienia wolności stała się readaptacja społeczna osadzonych. Pojawiły się nowe przepisy karne, rozporządzenia i ustawy oraz regulaminy organizacyjno-porządkowe stwarzające dobry grunt dla działalności naukowej, kulturalnej i resocjalizacyjnej bibliotek. W 2004 roku, gdy Polska przystąpiła do Unii Europejskiej, zaczęto dostosowywać więziennictwo do wymogów UE, a biblioteki więzienne do międzynarodowych wytycznych IFLA ${ }^{5}$.

Według wytycznych International Federation of Library Associations and Institutions z 2005 roku, dotyczących usług bibliotecznych dla skazanych, pomieszczenie biblioteczne powinno znajdować się w centrum więzienia, niedaleko wydziału edukacyjnego. Biblioteka powinna być dostępna dla jak największej liczby więźniów, dostosowana do osób niepełnosprawnych i powinna zatrudniać profesjonalnego bibliotekarza mającego niezbędne umiejętności i kwalifikacje. Gromadzone materiały powinny zaspokajać potrzeby informacyjne, edukacyjne, kulturalne, rekreacyjne i rehabilitacyjne. Księgozbiór powinien być kształtowany według planu uwzględniającego skład populacji więzienia oraz dostosowany do wieku i języka skazanych, poziomu ich edukacji i umiejętności czytelniczych.

${ }^{2}$ E.B. Zybert, Biblioteki więzienne, [w:] Encyklopedia książki, t. 1, red. A. Żbikowska-Migoń, M. Skalska-Zlat, Wrocław 2017, s. 348-349.

${ }^{3}$ E.B. Zybert, Biblioteki więzienne: zarys problematyki, Warszawa 1991, s. 40-45.

${ }^{4}$ Ibidem, s. 52-55.

${ }^{5}$ E.B. Zybert, Wspótczesne biblioteki więzienne i działalność kulturalno-oświatowa w polskich zakładach stużby więziennej, ,Przegląd Biblioteczny” 80, 2012, z. 1, s. 4. 
Oprócz literatury pięknej biblioteka powinna dysponować komiksami i powieściami graficznymi, materiałami dla początkujących czytelników oraz książkami z dużym drukiem dla więźniów z problemami ze wzrokiem, powinna też gromadzić audiobooki, czasopisma i gazety oraz podręczniki do nauki czytania, pisania, liczenia. Ważny jest również dostęp do Internetu, zapewniony w celach edukacyjnych, ale dostosowany do zasad bezpieczeństwa. W bibliotece powinny odbywać się wydarzenia promujące czytanie, literaturę i kulturę. Są one dla skazanych szansą na kreatywne spędzenie czasu, rozwijanie umiejętności społecznych, zwiększenie poczucia własnej wartości i podniesienie jakości życia. Przykładem takich wydarzeń mogą być spotkania z autorami książek, kluby dyskusyjne, warsztaty z pisania, konkursy recytatorskie i tym podobne ${ }^{6}$.

Według statystyk Centralnego Zarządu Służby Więziennej z 2014 roku w Polsce istnieje sto pięćdziesiąt pięć zakładów karnych i tyle samo bibliotek więziennych ${ }^{7}$, które funkcjonują na podstawie Rozporządzenia z 1999 roku, dotyczącego zasad organizacji usług bibliotecznych w zakładach karnych, poprawczych i schroniskach dla nieletnich oraz nawiązywania współpracy z bibliotekami publicznymi. Za zapewnienie warunków do działalności i rozwoju biblioteki odpowiada dyrektor danego więzienia. Jest on odpowiedzialny za przydzielenie odpowiedniego lokalu, zagwarantowanie doskonalenia zawodowego pracowników bibliotecznych i zaopatrywanie w środki finansowe niezbędne do wyposażenia biblioteki w potrzebne materiały oraz do prowadzenia codziennej działalności bibliotecznej. Księgozbiór odpowiada na zainteresowania i potrzeby osadzonych w miarę możliwości finansowych i lokalowych, gromadzony jest też osobny zbiór dla wyłącznego użytku funkcjonariuszy i pracowników Służby Więziennej. W Polsce oprócz prowadzenia biblioteki centralnej więzienie posiada również punkty biblioteczne rozmieszczone w oddziałach mieszkalnych, szpitalach, ośrodkach diagnostycznych, szkołach, oddziałach zewnętrznych i terapeutycznych. Raz na kwartał wymienia się zbiory z punktów na inne z biblioteki centralnej. Materiały udostępniane więźniom przebywającym w szpitalu lub w oddziałach zewnętrznych mają charakter niewymienny, są dezynfekowane i odpowiednio przygotowywane do korzystania. Doboru odpowiedniej literatury dokonuje wychowawca $\mathrm{z}$ bibliotekarzem lub funkcjonariuszem odpowiedzialnym za bibliotekę. Najlepszymi książkami dla skazanych są te, które pomagają im przetrwać okres pozbawienia wolności, pozwalają wyzbyć się negatywnych emocji oraz umożliwiają realizację programów terapeutycznych, edukacyjnych i kulturalno-oświatowych. Dodatkowo gromadzi się zbiory audiowizualne i multimedialne do publicznego odtwarzania oraz podręczniki i lektury szkolne na potrzeby szkół więziennych. Publikacje obcojęzyczne też powinny być dostępne, jednak zwykle

${ }^{6}$ Ibidem, s. 8-15.

7 Roczna informacja statystyczna za rok 2014, Warszawa 2014, s. 3 i 35, http://sw.gov.pl/ Data/Files/001c169lidz/rok-2014.pdf [dostęp: 26.05.2015]. 
są to podręczniki do nauki języka obcego. Nie jest to wielkie niedopatrzenie, gdyż cudzoziemcy odbywający karę pozbawienia wolności w Polsce stanowią niewielki odsetek populacji więziennej. Niedofinansowanie bibliotek więziennych powoduje zakup tylko najpotrzebniejszych książek, przez co propozycje i prośby osadzonych o kupno konkretnych tytułów są często ignorowane. Sytuację ratują dary od osób prywatnych, funkcjonariuszy Służby Więziennej, innych bibliotek, fundacji oraz organizacji pozarządowych ${ }^{8}$. Według statystyk na rok 2014 zbiory zgromadzone przez polskie biblioteki więzienne wynosiły 1559084 egzemplarzy. Wypożyczonych w tym roku zostało 892962 książek $^{9}$. Jest to najniższy wynik w ciągu ostatnich dziesięciu lat. Stan księgozbioru na rok 2013 wynosił 1594385 egzemplarzy, a liczba wypożyczeń to 1009600 książek. Jednakże w 2013 roku działało sto pięćdziesiąt sześć bibliotek więziennych, czyli o jedną więcej niż w 2014 roku $^{10}$. W ciągu ostatniego dziesięciolecia najwięcej materiałów bibliotecznych zgromadzono w roku 2009 (1 643344 egzemplarze), a najwięcej wypożyczano w 2008 (1 165 891). Księgozbiory powiększały się do 2009 roku, by do 2014 zmniejszać się o około 2\% co roku. Wyjątek stanowi rok 2013, kiedy zaobserwowano wzrost liczby materiałów bibliotecznych o prawie $1 \%$. Czytelnictwo wśród więźniów spada od 2008 roku. W roku $2012 \mathrm{w}$ porównaniu z rokiem poprzednim liczba wypożyczeń spadła aż o 7,4\%. W 2013 zaobserwowano wzrost wypożyczeń o 1,25\%, ale w 2014 zmniejszyły się one aż o 11,55\% ${ }^{11}$.

Więźniowie mogą korzystać ze wszystkich książek dostępnych w przeznaczonych im zbiorach lub korzystać z wypożyczania międzybibliotecznego. Jednak według Zarządzenia Dyrektora Generalnego Służby Więziennej z dnia 24 lutego 2004 roku nie należy udostępniać osadzonym materiałów o treści pornograficznej, eksponujących przemoc, niezgodnych z zasadami prawidłowego życia spo-

\footnotetext{
${ }^{8}$ E.B. Zybert, Współczesne..., s. 7-9.

${ }^{9}$ Roczna informacja statystyczna za rok 2014 ..

${ }^{10}$ Roczna informacja statystyczna za rok 2013, Warszawa 2013, http://sw.gov.pl/Data/Files/001c169lidz/rok-2013.pdf [dostęp: 26.05.2015].

${ }^{11}$ Roczna informacja statystyczna za rok 2012, Warszawa 2012, http:/sw.gov.pl/Data/Files/001c169lidz/rok-2012.pdf [dostęp: 26.05.2015]; Roczna informacja statystyczna za rok 2011, Warszawa 2011, http://sw.gov.pl/Data/Files/001142rdeb/rok-2011.pdf [dostęp: 26.05.2015]; Roczna informacja statystyczna za rok 2010, Warszawa 2010, http://sw.gov.pl/Data/Files/_public/rok-2010.pdf [dostęp: 26.05.2015]; Roczna informacja statystyczna za rok 2009, Warszawa 2009, http://sw.gov. pl/Data/Files/kunickim/statystyki/roczne/rok-2009.pdf [dostęp: 26.05.2015]; Roczna informacja statystyczna za rok 2008, Warszawa 2008, http://sw.gov.pl/Data/Files/kunickim/statystyki/roczne/ rok-2008.pdf [dostęp: 26.05.2015]; Roczna informacja statystyczna za rok 2007, Warszawa 2007, http://sw.gov.pl/Data/Files/kunickim/statystyki/roczne/rok-2007.pdf [dostęp: 26.05.2015]; Roczna informacja statystyczna za rok 2016, Warszawa 2006, http://sw.gov.pl/Data/Files/kunickim/statystyki/roczne/rok-2006.pdf [dostęp: 26.05.2015]; Roczna informacja statystyczna za rok 2005, Warszawa 2005, http://sw.gov.pl/Data/Files/kunickim/statystyki/roczne/rok-2005.pdf [dostęp: 26.05.2015]; Roczna informacja statystyczna za rok 2004, Warszawa 2004, http://sw.gov.pl/Data/Files/kunickim/ statystyki/roczne/rok-2004.pdf [dostęp: 26.05.2015].
} 
łecznego lub nieodpowiednich dla młodocianych przestępców ${ }^{12}$. Selekcji takich publikacji dokonuje wychowawca zarządzający biblioteką. Oprócz książek więźniowie mają dostęp do czasopism i prasy codziennej, kupowanej w ramach planu finansowego i dostarczanej przez administrację więzienną. Sami skazani mają możliwość prenumerowania periodyków na własny koszt lub otrzymywania ich od rodziny. Osadzeni mogą jednorazowo wypożyczyć od dwóch do sześciu egzemplarzy, chociaż zdarzają się przypadki nieograniczonej regulaminami liczby wypożyczeń. Najczęściej książki udostępniane są na okres od dwóch tygodni do miesiąca. Biblioteki więzienne muszą prowadzić katalogi kartkowe alfabetyczne i rzeczowe oraz katalogi zeszytowe, udostępniane w punktach bibliotecznych. Coraz popularniejsze stają się katalogi komputerowe. Według badań z 2008 roku $36,5 \%$ bibliotek ma już ten rodzaj katalogu bądź jest w trakcie jego tworzenia ${ }^{13}$.

W Polsce nie zatrudnia się wykwalifikowanych bibliotekarzy w więzieniach. Biblioteką zarządza i opiekuje się wyznaczony do tego wychowawca. Do jego obowiązków należy gromadzenie, opracowywanie, udostępnianie i utrzymywanie $\mathrm{w}$ odpowiednim stanie księgozbioru, prowadzenie ewidencji i statystyk dotyczących biblioteki, organizacja i nadzór nad funkcjonowaniem punktów bibliotecznych, czytelni czy wypożyczalni prasy. Odpowiedzialny jest również za popularyzację czytelnictwa oraz współpracę z bibliotekami publicznymi i innymi wychowawcami. Na wykonywanie tych wszystkich zadań w 2008 roku przeznaczano od pół do ośmiu godzin dziennie. W bibliotece mogą być zatrudnieni więźniowie, którzy zajmują się konserwacją i udostępnianiem zbiorów, prowadzeniem punktów bibliotecznych, obsługą studia radiowęzłowego i telewizyjnego, przygotowywaniem audycji i kompletowaniem nagrań oraz pomaganiem przy organizacji imprez zbiorowych. Nie mogą natomiast prowadzić ksiąg inwentarzowych, rejestru ubytków czy innej podobnej dokumentacji bibliotecznej ${ }^{14}$.

\section{Biblioteka miejscem resocjalizacji}

Biblioteka więzienna to istotne miejsce dla działalności terapeutycznej, tak zwanej twórczej resocjalizacji. Dotyczy ona przede wszystkim edukacji kulturalno-oświatowej, służy rozwojowi aktywności kulturalnej osadzonych oraz inicjuje, kształtuje i udoskonala ich zdolności artystyczne. W polskim środowisku penitencjarnym szerokim zainteresowaniem i uznaniem cieszy się Więzienny Klub Literacki „Bartnicka 10” z Włocławka, który aktywnie działa na rzecz wzbogacania aktywności kulturalnej osadzonych. Klub organizuje wieczory autorskie,

12 Zarządzenie nr 2/04 Dyrektora Generalnego Stużby Więziennej z dnia 24 lutego 2004 r., s. 3, http://www.bip.sw.gov.pl/Dokumenty/zarzadzenie_2wsprawieszczego $\%$ C5\%82owychzasadp rowadzeniaiorganizacjipracy.pdf [dostęp: 30.05.2015].

${ }^{13}$ E.B. Zybert, Współczesne..., s. 12-13.

${ }^{14}$ Ibidem, s. 15-16. 
spotkania z poezją, warsztaty literackie, konkursy i zbiorowe wyjścia na imprezy kulturalne w bibliotekach publicznych, muzeach czy galeriach sztuki. Więźniowie redagują „Gazetę Więzienną,, na łamach której prezentowana jest twórczość literacka ich kolegów. Wydawanie periodyków przez skazanych jest praktykowane również w Zakładzie Karnym w Barczewie („Aby do wokandy”), w okręgu białostockim („Przystanek”), w Zakładzie Karnym w Łowiczu („Pasiaczek”), Zakładzie Karnym w Koszalinie („Errata”) i w Grudziądzu („Naszym zdaniem”). Do popularyzacji czytelnictwa i promowania zbiorów biblioteki więziennej najczęściej wykorzystywany jest radiowęzeł, przez który można prezentować nowe nabytki biblioteki, prowadzić audycje poświęcone książkom, a nawet emitować audiobooki. W 2008 roku w Zakładzie Karnym w Chełmie osadzeni mogli wysłuchać dwudziestu książek przeczytanych w pięćdziesięciominutowych audycjach. Organizowane są również wystawy książek oraz konkursy, nie tylko z wiedzy literackiej, ale również z zakresu historii, geografii, muzyki, sportu i filmu ${ }^{15}$.

Czytanie książek zaspokaja wiele podstawowych potrzeb psychicznych człowieka i dobrze wpływa na jego rozwój oraz funkcjonowanie w społeczeństwie. Poprzez kontakt z literaturą czytelnik doświadcza wielu emocji, przyswaja nowe informacje o otaczającym go świecie oraz uczy się różnych wzorców zachowania, przez co rozwija swoją empatię. Oprócz tego książka dostarcza rozrywki, pobudza wrażenia estetyczne i ekspresję artystyczną ${ }^{16}$. Wszystkie te funkcje są niezwykle ważne dla osób pozbawionych wolności. Według badań więźniowie bardzo często nie mają poczucia sensu życia, które odgrywa ważną rolę w poprawnym kształtowaniu się osobowości. Dodatkowo skazani mają niskie poczucie szczęścia, są neurotyczni i skryci oraz bardzo podejrzliwi w stosunku do innych ludzi ${ }^{17}$. Literatura piękna może być dla nich źródłem wiedzy o świecie i innych ludziach, konfrontacją własnych problemów z problemami bohaterów książek oraz pomocą przy rozwiązywaniu dylematów moralnych i kształtowaniu własnego światopoglądu. Dzięki książkom popularnonaukowym więźniowie mogą się dokształcać, rozwijać swoje zainteresowania i udoskonalać umiejętności zawodowe, ale również uzyskać aktualne informacje społeczne, kulturalne, polityczne czy historyczne ${ }^{18}$. „Wierzę w moc literatury, która może być deską ratunkową, na niej opiera się cywilizacja"19 - tymi słowami Agnieszka Kłos skomentowała swój pomysł podarowania książek więźniom. Akcja „Książka za kraty” miała być wydarze-

15 Ibidem, s. 19-25.

${ }^{16}$ B. Szczupał, Terapeutyczna funkcja biblioterapii w resocjalizacji i profilaktyce społecznej, [w:] Terapia w resocjalizacji. Cz. I, ujęcie teoretyczne, red. A. Rejzner, P. Szczepaniak, Warszawa 2009, s. 230-231.

17 D.M. Boruc, Poziom satysfakcji z życia i poziom inteligencji emocjonalnej wśród skazanych mężczyzn odbywających karę pozbawienia wolności w polskich zakładach karnych, Kraków 2015, s. 146-147.

18 B. Szczupał, op. cit., s. 232.

19 J. Sobolewska, Siedza i czytaja, „Polityka” 2014, nr 33, s. 100. 
niem jednorazowym, jednak spotkała się $\mathrm{z}$ tak dużym entuzjazmem ze strony skazanych i darczyńców, że po trzech latach odbyła się ponownie. Dzięki temu biblioteka więzienna Zakładu Karnego w Rawiczu wzbogaciła się w 2013 roku o około trzydzieści tysięcy książek. Jednakże przez powszechny dostęp do telewizora i playstation czytanie jest $\mathrm{w}$ więzieniach coraz mniej popularne ${ }^{20}$.

\section{Badanie czytelnictwa więźniów w Polsce}

W Polsce badaniem czytelnictwa więźniów zajmowała się Aleksandra Chwastek, która w 1980 roku opublikowała wyniki swoich obserwacji i ankiet przeprowadzonych w trzech największych polskich zakładach karnych. Badanie objęło grupę więźniów młodocianych, skazanych podlegających karze po raz pierwszy, z wyrokami do pięciu lat oraz osadzonych dożywotnio i recydywistów ${ }^{21}$. Badaczka zebrała ankiety od siedmiuset dziesięciu skazanych, przeprowadziła sto pięćdziesiąt wywiadów oraz uczestniczyła w lekcjach, wydarzeniach kulturalnych i różnych imprezach organizowanych na terenie placówek ${ }^{22}$. Wyniki i wnioski z badań mogą być zaskakujące. Większość ankietowanych przyznała, że rzadziej czyta w więzieniu z uwagi na brak czasu i złe warunki. Natomiast czytający osadzeni przyznali, że do sięgnięcia po książkę motywuje ich nuda, brak innych rozrywek i potrzeba dokształcenia się. Największym zainteresowaniem cieszyła się literatura o tematyce historycznej, kryminalnej i podróżniczej. Wśród ulubionych tytułów skazani wymieniali pozycje Henryka Sienkiewicza z Trylogią na czele. Dużą popularnością cieszył się również Winnetou Karola Maya i Pan Tadeusz Adama Mickiewicza. Tylko $8,5 \%$ badanych przyznało, że nie czyta gazet ani czasopism, tłumacząc to niechęcią i brakiem zainteresowania. Wszystkie te osoby nie ukończyły szkoły podstawowej. Chwastek zauważyła, że czytelnictwo więźniów zależy głównie od pracy biblioteki i bibliotekarzy. Aktualny i interesujący księgozbiór, czytelne i dobrze opracowane katalogi oraz wykształceni i ambitni bibliotekarze znacząco wpłynęliby na czytelnictwo, powodując jego wzrost. Dodatkowo autorka upatrywała w lekturze funkcji resocjalizacyjnej, zwiastując tym rosnący potencjał biblioterapii ${ }^{23}$.

Inną badaczką zainteresowaną pracą bibliotek więziennych była Elżbieta Barbara Zybert, która 1991 roku opublikowała obszerną pracę komentującą funkcjonowanie bibliotek w zakładach karnych na początku lat osiemdziesiątych XX wieku. Jej badania dotyczyły jednak bardziej wielkości księgozbiorów, czasu poświęcanego na udostępnianie i opracowywanie materiałów bibliotecznych, liczby wykwalifikowanych bibliotekarzy oraz pomieszczeń bibliotecznych, mniej

\footnotetext{
${ }^{20}$ Ibidem.

21 A. Chwastek, Studia nad czytelnictwem więźniów, Wrocław 1980, s. 57.

22 Ibidem, s. 27-29.

${ }^{23}$ Ibidem, s. 80-118.
} 
skupiała się na czytelnictwie skazanych ${ }^{24}$. Zybert powróciła do swoich badań w 2012 roku, porównując ówczesny stan bibliotek więziennych z wynikami jej wcześniejszej pracy z 1981 roku.

Problemem czytelnictwa więźniów zainteresowała się dopiero w 2015 roku Fundacja Zmiana i przeprowadziła ankietę w Areszcie Śledczym Warszawa-Białołęka, Areszcie Śledczym Warszawa-Białołęka Oddział Zewnętrzny Bemowo, Areszcie Śledczym Warszawa-Grochów, Zakładzie Karnym Nr 1 w Strzelcach Opolskich, Areszcie Śledczym w Płońsku i Areszcie Śledczym w Hajnówce. Badanie zostało przeprowadzone wśród pięciuset dwudziestu siedmiu osób, 81\% stanowili mężczyźni, 19\% kobiety, a na zespół badawczy składały się osoby bez profesjonalnego przeszkolenia. Dodatkowo respondentami w większości były osoby biorące udział w programie „Książki w pudle”, który jest projektem z dziedziny animacji społecznej i kulturalnej, oraz skazani wybrani przez funkcjonariuszy Służby Więziennej. Dlatego nie należy traktować wyników tej ankiety dosłownie, jako obraz całościowy polskiego czytelnictwa więziennego i trzeba pamiętać, że w związku z aktywizacją osadzonych za pomocą programu „Książki w pudle” rezultat badania może być zawyżony ${ }^{25}$. Na pytanie, czy respondent czyta obecnie więcej książek niż na wolności, aż 69\% ankietowanych odpowiedziało, że częściej sięga po książkę niż przed pobytem w więzieniu. Aż $36 \%$ badanych zadeklarowało, że czyta książki prawie codziennie, $26 \%$ co najmniej raz w miesiącu, a 16\% raz na jakiś czas („,co kilka miesięcy coś przeczytam"). Tylko $8 \%$ przyznało, że w ogóle nie czyta, a $14 \%$ prawie w ogóle. Wyniki robią wrażenie, zwłaszcza jeśli porówna się je z rezultatami badań Biblioteki Narodowej dotyczącymi czytelnictwa Polaków (w 2015 roku tylko 37\% ankietowanych zadeklarowało lekturę co najmniej jednej książki ${ }^{26}$ ).

Wśród przebadanych więźniów największą popularnością cieszyły się książki oparte na faktach, trochę mniej pożądana była literatura praktyczna, a najmniej literatura piękna. Wśród osób, które zadeklarowały w ankiecie, że chciałyby czytać więcej, ale napotykają na problemy, najwięcej odpowiedzi dotyczyło źle wyposażonej biblioteki. Respondenci skarżyli się na brak zróżnicowanej literatury, zgłaszali zapotrzebowanie na książki przygodowe, fantastyczne, a nawet bajki. Drugą trudnością zniechęcającą do sięgania po literaturę były złe warunki do czytania. Ankietowani narzekali na brak ciszy i złe oświetlenie. Najmniej osób odpowiedziało, że nie może czytać przez złe samopoczucie. Osadzeni wyjaśniali, że przez problemy rodzinne, uzależnienia, pragnienie wolności nie są w stanie się skoncentrować ${ }^{27}$.

24 E.B. Zybert, Biblioteki więzienne: zarys..., s. 60-88.

${ }^{25}$ K. Lipińska, Książki nie dziela: raport o czytelnictwie $w$ polskich zakładach karnych, [b.m.] 2015, s. 6-8, http://fundacjazmiana.pl/wp-content/uploads/2015/06/ksiazki_w_pudle.pdf [dostęp: 28.12.2017].

${ }^{26}$ Podstawowe wyniki badań czytelnictwa za rok 2015, http://www.bn.org.pl/download/document/1457976203.pdf [dostęp: 14.04.2016 r.].

${ }^{27}$ K. Lipińska, op. cit., s. 12-30. 


\section{Czytelnictwo więźniów Zakładu Karnego w Rawiczu}

W kwietniu 2016 roku w Zakładzie Karnym w Rawiczu przeprowadziłam ankietę, która miała na celu zbadanie czytelnictwa i zainteresowań czytelniczych osadzonych. Kwestionariusz składał się z dziesięciu pytań, które dotyczyły częstotliwości czytania książek i czasopism, zainteresowań czytelniczych i zadowolenia ze zbiorów biblioteki więziennej oraz korzystania z czytelni. W badaniu wzięło udział pięćdziesięciu mężczyzn, którzy wyrazili chęć wypełnienia ankiety. Statystyczny respondent miał trzydzieści pięć lat (wykres 1), wykształcenie zasadnicze zawodowe (wykres 2), został skazany na rok do pięciu lat w zakładzie karnym (wykres 3) i był to jego pierwszy pobyt w placówce o takim charakterze. Średni czas spędzony za murami więzienia przez jednego osadzonego to czterdzieści cztery miesiące.



Wykres 1 . Wiek ankietowanych

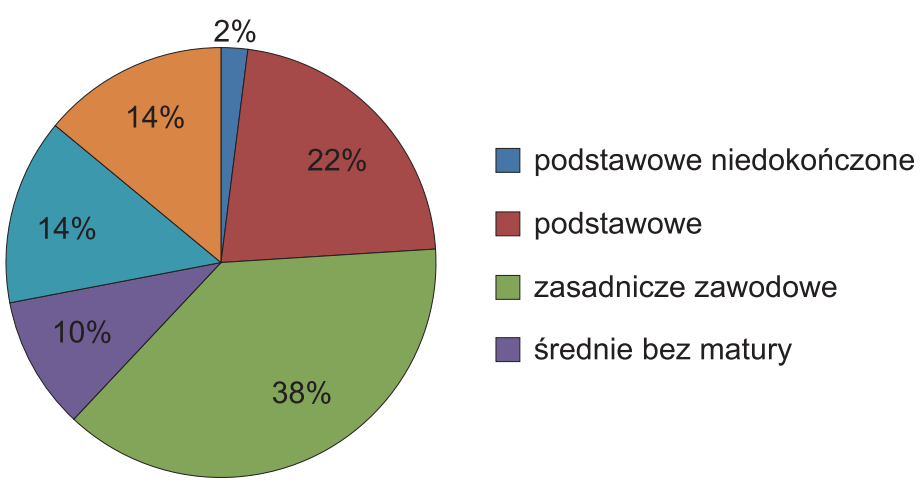

Wykres 2. Wykształcenie ankietowanych 


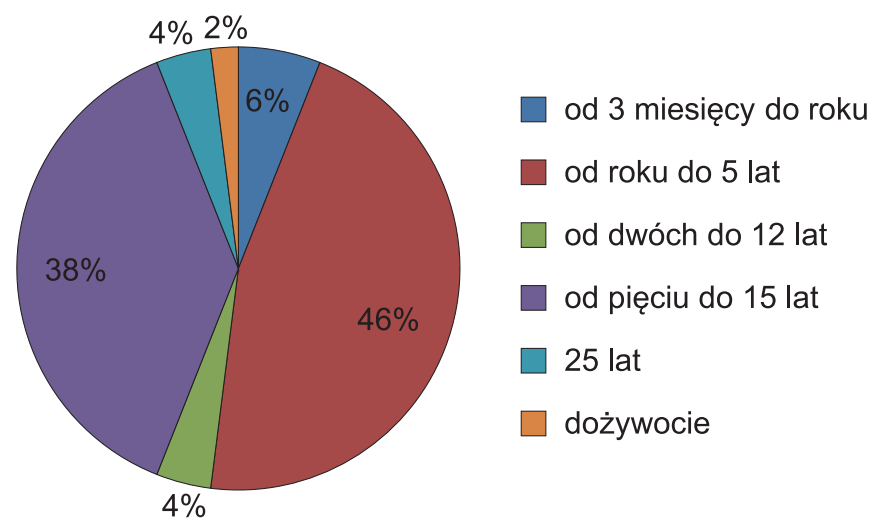

Wykres 3. Długość wyroku ankietowanych

Aż $90 \%$ badanych zadeklarowało czytanie książek, natomiast trzy osoby uznały, że nie mają takiej potrzeby, a dwie przyznały, że tego nie lubią. Jednakże wszyscy ankietowani oznajmili, że biblioteka w więzieniu jest potrzebna. Wśród czytających respondentów codzienną lekturę zadeklarowało dwanaście osób (26,7\%), prawie codziennie po książkę sięgało siedemnaście osób (37,8\%), co najmniej raz w miesiącu trzynaście osób (28,8\%), a raz na jakiś czas trzy osoby (6,7\%). Znaczna większość, bo aż $69 \%$ ankietowanych, przyznało, że obecnie czyta więcej niż przed pobytem w więzieniu, a tylko dwie osoby uznały, że czytają rzadziej niż na wolności.

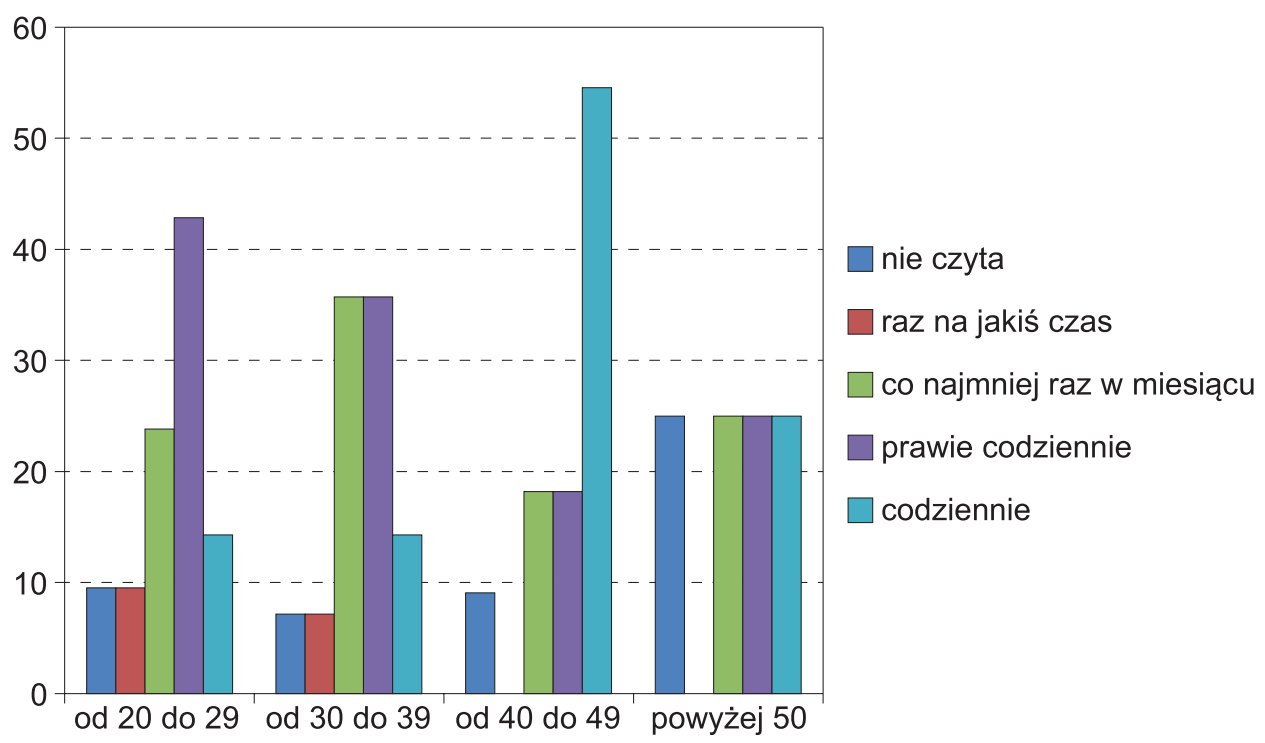

Wykres 4. Stosunek wieku skazanych do częstotliwości czytania

W przedziale wiekowym 20-29 lat największy procent osadzonych $(42,86 \%)$ zadeklarował czytanie prawie codziennie. Trochę mniej osób $(23,81 \%)$ przyznało, że czyta co najmniej raz w miesiącu. Trzy osoby zadeklarowały codzienną 
lekturę, natomiast dwie osoby zgłosiły, że nie czytają w ogóle i tyle samo osób przyznało, że czytają raz na jakiś czas.

Więźniowie w wieku od 30 do 39 lat czytali co najmniej raz w miesiącu lub prawie codziennie (po 35,71\% badanych). Pojedyncze osoby przyznały się do nieczytania bądź do czytania raz na jakiś czas. 14,3\% respondentów z tej grupy wiekowej zadeklarowało codzienne czytanie.

Skazani po czterdziestym roku życia w zdecydowanej większości (54,55\%) oświadczyli, że czytają codziennie. Po tyle samo osób przyznało, że prawie codziennie i co najmniej raz w miesiącu czytają książki. Jedna osoba przyznała, że nie czyta w ogóle.

Osoby powyżej pięćdziesiątego roku życia stanowiły mniejszość wśród badanych (czterech respondentów). Każdy z respondentów zadeklarował inną częstotliwość czytania: jedna osoba nie czytała w ogóle, inna co najmniej raz w miesiącu, kolejna prawie codziennie, ostatnia codziennie.

Podsumowując, można zauważyć skok czytelnictwa u skazanych po czterdziestym roku życia. Tylko w tej grupie wiekowej codzienną lekturę zadeklarowała przeważająca liczba osób. Cieszy również poziom prawie codziennego czytelnictwa w pozostałych grupach. Nie można jednak stwierdzić, czy wiek skazanych ma jakikolwiek wpływ na częstotliwość czytania przez nich książek.

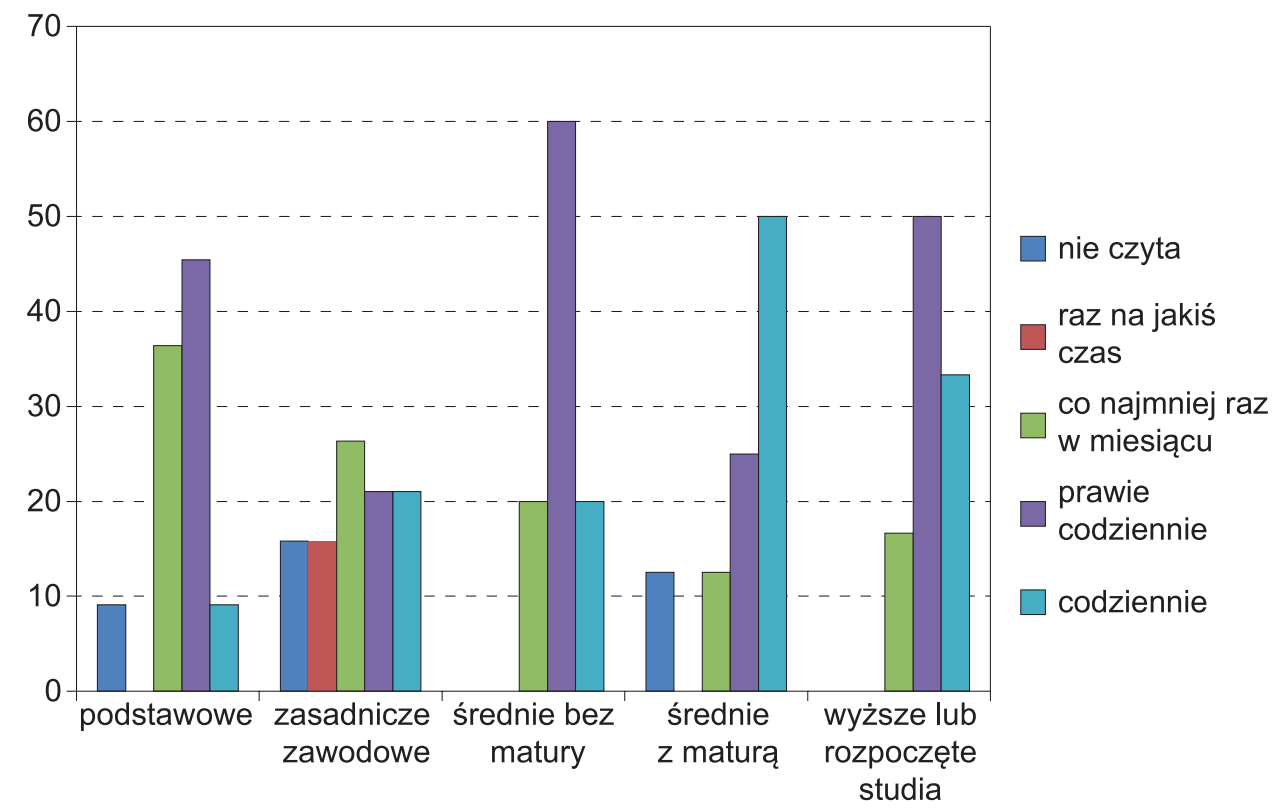

Wykres 5. Stosunek wykształcenia skazanych do częstotliwości czytania

Wśród badanych znalazła się osoba, która nie ukończyła szkoły podstawowej i która zadeklarowała czytanie co najmniej raz w miesiącu. Wśród więźniów z wykształceniem podstawowym najwięcej osób $(45,45 \%)$ zadeklarowało czytanie prawie 
codzienne. Mniej badanych (36,37\%) przyznało, że czytało co najmniej raz w miesiącu. Po jednej osobie z tej grupy zgłosiło czytanie codzienne oraz nieczytanie w ogóle.

Osoby z wykształceniem zasadniczym zawodowym stanowiły najliczniejszą grupę wśród skazanych. Wśród nich najwięcej badanych czytało co najmniej raz w miesiącu (26,32\%), niewiele mniej respondentów czytało prawie codziennie i codziennie (po 21,05\%), a najmniej było osób czytających raz na jakiś czas i nieczytających (po 15,79\%).

Więźniowie z wykształceniem średnim, lecz bez matury, w zdecydowanej większości (60\%) zadeklarowali czytanie prawie codziennie. Pozostali czytali co najmniej raz w miesiącu i codziennie (po 20\%). W tej grupie nie było osób, które nie czytałyby w ogóle bądź sporadycznie.

Połowa skazanych z wykształceniem średnim ze zdaną maturą przyznała, że czyta codziennie, natomiast $25 \%$ respondentów zadeklarowało prawie codzienną lekturę. Jedna osoba zgłosiła, że nie czyta w ogóle oraz jedna, że czyta co najmniej raz w miesiącu.

$\mathrm{W}$ grupie z wykształceniem wyższym bądź rozpoczętymi studiami połowa ankietowanych czytała prawie codziennie. Trochę mniej osób $(33,34 \%)$ przyznało, że czytało codziennie, a jedynie $16,66 \%$ zgłosiło, że czytało co najmniej raz w miesiącu. W tej grupie, podobnie jak u skazanych ze średnim wykształceniem bez matury, nie było osób nieczytających bądź czytających raz na jakiś czas.

Podsumowując, należy stwierdzić, że wykształcenie zdaje się mieć wpływ na częstotliwość czytania wśród skazanych. Można zauważyć znaczący wzrost czytania prawie codziennego zaczynający się od grupy z wykształceniem średnim bez matury oraz codziennego $\mathrm{w}$ grupie $\mathrm{z}$ wykształceniem średnim $\mathrm{z}$ maturą. Cieszy również częstotliwość czytania u osób z wykształceniem podstawowym. Można sądzić, że pomimo szybkiego zakończenia edukacji te osoby nadal chcą zdobywać wiedzę i poszerzać swoje horyzonty.



Wykres 6. Stosunek wyroku otrzymanego przez skazanego do częstotliwości czytania 
Najwięcej więźniów, bo blisko połowa (wykres 3), odbywała karę pozbawienia wolności z przedziału od roku do 5 lat. Wśród nich czytelnictwo było na wysokim poziomie. Większość (30,42\%) zadeklarowała, że czyta codziennie. Prawie codziennie i co najmniej raz na miesiąc czytało po $26 \%$ badanych. Dwie osoby przyznały, że nie czytają i tyle samo skazanych zgłosiło, że czytają raz na jakiś czas.

Drugą najliczniejszą grupę stanowili więźniowie odbywający karę pozbawienia wolności od 5 do 15 lat. Ponad połowa z nich (52,63\%) zadeklarowała prawie codzienną lekturę. Trochę mniej osób (31,58\%) przyznało, że czyta co najmniej raz w miesiącu. Pozostali więźniowie czytali codziennie (10,53\%) lub sporadycznie $(5,26 \%)$. Nie było w tej grupie nikogo, kto nie czytałby w ogóle.

$\mathrm{W}$ pozostałych grupach było niewiele osób. $\mathrm{Z}$ trzech skazanych z wyrokiem od trzech miesięcy do roku pozbawienia wolności, każdy inaczej zadeklarował częstotliwość czytania: jeden osadzony nie czytał w ogóle, jeden co najmniej raz w miesiącu i jeden codziennie. Dwóch więźniów z wyrokiem od dwóch do dwunastu lat pozbawienia wolności przyznało, że czytają codziennie, natomiast jedna osoba z wyrokiem dwudziestu pięciu lat pozbawienia wolności zgłosiła, że czyta prawie codziennie. Inny skazany na dwadzieścia pięć lat więzienia przyznał, że nie czyta, podobnie jak mężczyzna skazany na dożywocie.

Nie wydaje się, by otrzymany wyrok, a co za tym idzie rodzaj popełnionego wykroczenia, miał jakikolwiek wpływ na częstotliwość czytania książek.

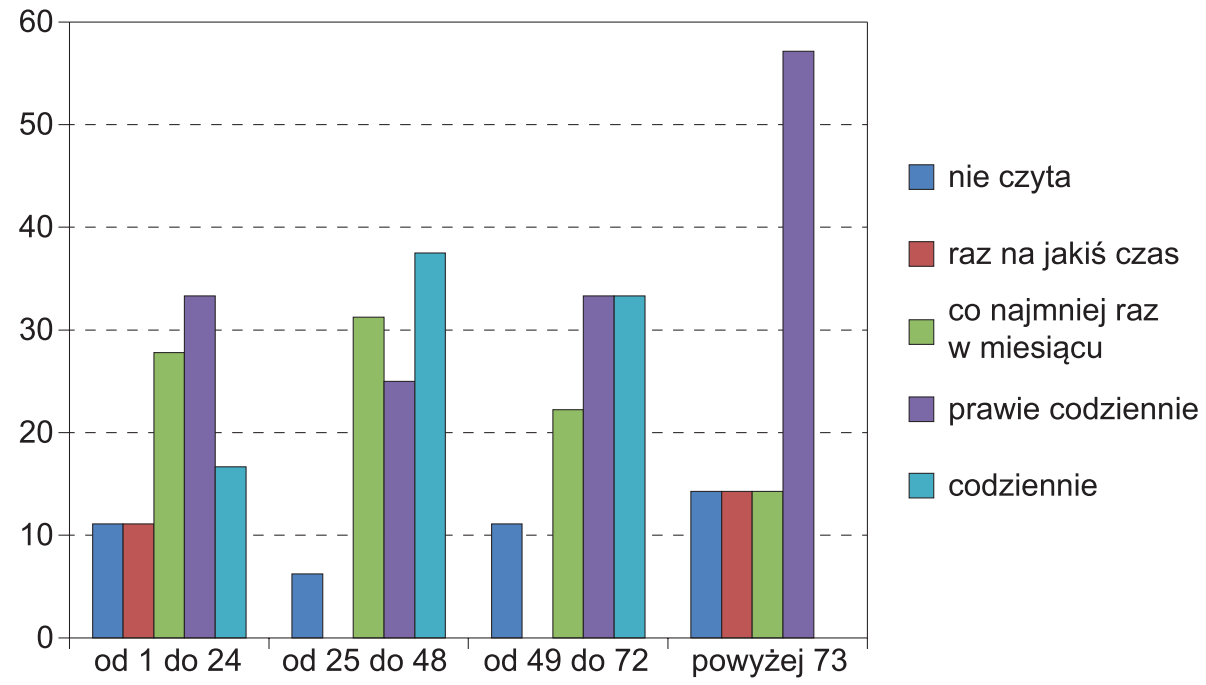

Wykres 7. Stosunek czasu spędzonego w więzieniu przez skazanego (w miesiącach) do częstotliwości czytania

Wśród osadzonych, którzy spędzili w więzieniu czas w przedziale od miesiąca do dwóch lat, najwięcej było osób czytających prawie codziennie. Trochę mniej badanych z tej grupy zadeklarowało, że czyta co najmniej raz w miesiącu. Ponad 
$16 \%$ skazanych przebywających w zakładzie karnym w tym przedziale czasowym czytało codziennie. Dwie osoby przyznały, że nie czytają i tyle samo zgłosiło, że czyta raz na jakiś czas.

Spośród więźniów mających za sobą od dwudziestu pięciu do czterdziestu ośmiu miesięcy w zakładzie karnym najwięcej (37,5\%) zadeklarowało codzienną lekturę. Trochę mniej osób $(31,25 \%)$ przyznało, że czyta co najmniej raz w miesiącu oraz prawie codziennie (25\%). Jedna osoba zgłosiła, że nie czyta w ogóle.

Tyle samo skazanych $(33,33 \%)$ mających za sobą od czterdziestu dziewięciu do siedemdziesięciu dwóch miesięcy pobytu w zakładzie karnym zadeklarowało codzienną oraz prawie codzienną lekturę. Mniej osób przyznało, że czyta co najmniej raz w miesiącu, a jedna osoba, że nie czyta w ogóle.

Wśród osadzonych, którzy mają za sobą siedemdziesiąt trzy lub więcej miesięcy pobytu w więzieniu nie było nikogo, kto czytałby codziennie. Natomiast prawie codzienną lekturę zadeklarowała ponad połowa tej grupy. Pojedyncze osoby przyznały, że czytają co najmniej raz w miesiącu, raz na jakiś czas lub nie czytają w ogóle.

Trudno jednoznacznie stwierdzić, czy czas, jaki skazany już spędził w zakładzie karnym, ma wpływ na jego częstotliwość czytania. Wydaje się, że czas dwóch-trzech lat w więzieniu jest dla osadzonego przełomowy i wtedy czytelnictwo rośnie, lecz na podstawie zaprezentowanego badania nie można stwierdzić tego na pewno.

Wszyscy czytający badani oświadczyli, że korzystali ze zbiorów biblioteki, chociaż pojawiły się komentarze, że część książek osadzeni dostali od swoich rodzin. Co najmniej raz w miesiącu biblioteczne lektury wypożyczało $65 \%$ ankietowanych, codziennie i prawie codziennie korzystało z nich $22 \%$ badanych, a tylko $13 \%$ określiło częstotliwość ich użytkowania jako raz na jakiś czas. Zadowolenie z bibliotecznych zbiorów książek zadeklarowało 86,7\% respondentów, jednakże sześć osób uznało je za niewystarczające. Pytani uznali, że najbardziej brakuje im książek religijnych, edukacyjnych oraz nowości literackich. Pojawiły się komentarze zgłaszające zapotrzebowanie na literaturę z dziedziny fizyki, ekonomii oraz psychologii, głównie o charakterze podręczników do terapii uzależnień. Jeden $\mathrm{z}$ ankietowanych podał konkretne tytuły, których według niego brakuje: Ulisses Jamesa Joyce'a, Szatańskie wersety Salmana Rushdiego oraz Rozmowy z katem Kazimierza Moczarskiego. Badani najchętniej czytają literaturę piękną, wśród której najczęściej wymieniają fantastykę (dziewięć osób), kryminały (osiem osób), sensację i horrory (po cztery osoby). Pojawiły się również ulubione tytuły powieści między innymi Pamiętnik Nicolasa Sparksa i Skrytoświat Williama Horwooda. Rzadziej czytana jest literatura oparta na faktach (26\% odpowiedzi) i książki dotyczące zagadnień praktycznych (20\% odpowiedzi). Pojawiło się również kilka pozycji określonych jako „inne”. W komentarzach badani informowali, że lubią czytać książki podróżnicze, religijne oraz z dziedziny parapsychologii. 
Prawie wszyscy ankietowani odpowiedzieli, że czytają czasopisma. Tylko jedna osoba przyznała, że tego nie robi, ponieważ podobnie jak w kwestii czytania książek, nie odczuwa takiej potrzeby. W Zakładzie Karnym w Rawiczu z większości czasopism można korzystać wyłącznie w czytelni, do której dostęp jest ograniczony. Tylko jedna osoba przyznała, że korzystała z niej codziennie, kolejne dwie - prawie codziennie. Większość ankietowanych (dwadzieścia jeden osób) przebywała w czytelni raz w miesiącu lub raz na jakiś czas (osiem osób), natomiast trzy osoby prawie w ogóle jej nie odwiedzały, a piętnastu skazanych nie bywało tam w ogóle. Brak potrzeby korzystania z czytelni, jak wynika z komentarzy, jest spowodowany tym, że większość prasy osadzeni otrzymywali od swojej rodziny i mogli czytać swoje egzemplarze w celi. Pomimo to $86 \%$ ankietowanych przyznało, że są zadowoleni ze zbiorów czasopism dostępnych w bibliotece więziennej. $14 \%$ pytanych uznało, że prasy nie wystarcza i jest ona za mało zróżnicowana. W komentarzach pojawiły się sugestie zakupu czasopism chrześcijańskich, naukowych (między innymi „Świat Wiedzy”, „Wiedza i Życie”), informatycznych i fantastycznych (na przykład „Nowa Fantastyka”). Jednakże najwięcej komentarzy dotyczyło aktualnej prasy informacyjnej, takiej jak „Gazeta Wyborcza” i „Rzeczpospolita”.

Autorka badania dzięki kilku rozmowom z przypadkowymi osadzonymi dowiedziała się również, że więźniowie przechodzący terapię odwykową bardzo doceniają książki o uzależnieniach, ponieważ dzięki nim zdobywają wiedzę na temat, który bezpośrednio ich dotyczy, są bardziej świadomi tego, co się z nimi dzieje, a w przyszłości będą lepiej przygotowani do walki ze swoimi słabościami. Pojawiły się również opinie mówiące o tym, że skazani poprzez kontakt z literaturą uczą się nowych rzeczy, odkrywają swoje pasje, a poprzez utożsamianie się z bohaterami książek stają się bardziej empatyczni. Pozwala im to lepiej zrozumieć swoją sytuację i emocje, ale daje im również możliwość ucieczki od przykrej dla nich rzeczywistości.

Podsumowując, poziom czytelnictwa więźniów Zakładu Karnego w Rawiczu można określić jako wysokie. Większość respondentów przyznała, że czytała w więzieniu więcej niż na wolności. Nasuwa się wniosek, że pobyt w zakładzie karnym jest dobrym czasem na wykształcenie zainteresowań czytelniczych wśród osadzonych, nabycie przez nich nowej wiedzy i doświadczeń, dzięki czemu inaczej spojrzą na rzeczywistość i innych ludzi. Większą popularnością od książek cieszy się prasa - można przypuszczać, że skazanym bardzo zależy na aktualnych informacjach o wydarzeniach poza więzieniem. Również więzienna gazetka „Ocenzurowano" ma duże grono czytelników, więc być może krótsze formy wypowiedzi pisemnej są bardziej atrakcyjne dla więźniów. Większość osadzonych zadeklarowała wykształcenie zasadnicze zawodowe oraz podstawowe, co oznacza, że czas, w którym mogli odnaleźć swoje zainteresowania i rozszerzyć horyzonty, był bardzo ograniczony. Wiek i długość wyroku zdają się nie mieć wpływu na częstotliwość czytania wśród osadzonych w Zakładzie Karnym w Rawiczu. 
Wskazane przez osadzonych luki w zbiorach bibliotecznych pokazują bezsprzecznie konieczność bieżącego aktualizowania zbiorów i dostosowania ich tematyki do potrzeb tych specyficznych czytelników.

\section{Zakończenie}

Biblioteki więzienne to temat mało popularny $\mathrm{i}$ bardzo rzadko będący w kręgu naukowego zainteresowania. Jednakże, jak wykazała ankieta, biblioteka w zakładzie karnym jest potrzebna skazanym, którzy chętnie z niej korzystają i są zadowoleni z jej funkcjonowania. Tkwi w niej potencjał, który warto zauważyć i zgłębić. W szybko zmieniającym się świecie, zdominowanym przez technologię, w którym literatura odchodzi w zapomnienie i coraz mniej ludzi ją czyta, specjalna grupa, którą tworzą więźniowie, stanowi szansę dla ponownego rozbudzenia zainteresowania czytelnictwem. Książka, jako główne narzędzie biblioterapii, służy do rozrywki i sprawia przyjemność, ale też powinna być pomocna w rozwiązywaniu problemów i zdobywaniu wiedzy. Natomiast biblioteka to nie tylko księgozbiór, lecz również miejsce spotkań i wydarzeń kulturalnych. Wychodząc na wolność, osadzony powinien wiedzieć, że w bibliotece znajdzie pomoc i zawsze będzie mile widziany. Dlatego współpraca między biblioteką więzienną a publiczną to dobry pomysł, który pozwoliłby skazanym oswoić się z tą instytucją i zachęciłby ich do korzystania z jej usług w przyszłości. Dodatkowo większa liczba książek, audiobooków i innych multimediów zachęcałaby więźniów do oderwania się od telewizora czy playstation.

Brak publikacji z tego zakresu jest zaskakujący i niepokojący. Być może taki stan rzeczy wynika ze specyfiki miejsca, jakim jest zakład karny i z trudności $\mathrm{z}$ dostaniem się na teren placówki. Innym powodem mogą być blokady psychologiczne naukowców, którzy mogą odczuwać lęk przed więzieniem lub po prostu uważają, że są ważniejsze i ciekawsze tematy do badań. Polskie więziennictwo zmaga się z wieloma problemami: przeludnieniem zakładów karnych, wysokim wskaźnikiem recydywy, wątpliwościami co do sensu resocjalizacji i być może dlatego zagadnienia związane z bibliotekami więziennymi zostały zepchnięte na boczny tor. Jednakże wpływ książki na więźniów i ich resocjalizację wydaje się istotną, ważną kwestią mogącą zmienić rodzaje terapii, podejście pedagogów i opiekunów oraz zachowanie samych skazanych. Jak wynika z badania, penitencjariusze czytają literaturę i prasę, odnajdują w tym przyjemność i pomoc oraz chcą się rozwijać i zdobywać nową wiedzę. Interesującym tematem do dalszych badań jest czytelnictwo skazanych i ich podejście do książki w innych zakładach karnych w Polsce. Również funkcjonowanie i działalność polskich bibliotek więziennych powinno być zbadane. Na podstawie takich ogólnokrajowych badań można by utworzyć ujednolicony, wzorcowy model więziennej biblioteki, 
dostosowany do polskich realiów, do którego opiekunowie bibliotek mogliby dążyć. Oczywiście zakłady karne są pod wieloma względami zróżnicowane i to również należałoby wziąć pod uwagę przy tworzeniu profilu biblioteki. Dlatego istotne byłyby badania czytelnictwa różnych typów więźniów (młodocianych, recydywistów, skazanych na najwyższy wymiar kary) w celu sprawdzenia, czy ich oczekiwania wobec biblioteki się różnią i czy literatura wpływa na nich inaczej. Interesujące oraz znaczące byłyby również badania łączące bibliotekoznawstwo z resocjalizacją lub psychologią, sprawdzające, czy książki i wydarzenia kulturalno-oświatowe oddziałują na poczucie sensu życia skazanych, zmianę postrzegania przez nich rzeczywistości i innych ludzi oraz na radzenie sobie z problemami.

Biblioteki więzienne są więc tematem ciekawym i wartym szerszego zbadania. Dla więźniów i bibliotek jest to szansa na zmianę na lepsze, na rozwój i poprawienie jakości życia.

\section{Bibliografia}

Boruc D.M., Poziom satysfakcji z życia i poziom inteligencji emocjonalnej wśród skazanych mężczyzn odbywających karę pozbawienia wolności w polskich zakładach karnych, Kraków 2015.

Chwastek A., Studia nad czytelnictwem więźniów, Wrocław 1980.

Lehmann V., Locke J., IFLA: Guidelines for library services to prisoners, The Hague 2005, http:// www.ifla.org/files/assets/hq/publications/professional-report/92.pdf [dostęp: 26.05.2015].

Lipińska K., Książki nie dziela: raport o czytelnictwie $w$ polskich zaktadach karnych, [b.m.], 2015 http://fundacjazmiana.pl/wp-content/uploads/2015/06/ksiazki_w_pudle.pdf [dostęp: 28.12.2017].

Podstawowe wyniki badań czytelnictwa za rok...,http://www.bn.org.pl/download/document/1457976203. pdf [dostęp: 14.04.2016 r.]

Roczna informacja statystyczna za rok 2004, Warszawa 2004, http://sw.gov.pl/Data/Files/kunickim/ statystyki/roczne/rok-2004.pdf [dostęp: 26.05.2015].

Roczna informacja statystyczna za rok 2005, Warszawa 2005, http://sw.gov.p1/Data/Files/kunickim/ statystyki/roczne/rok-2005.pdf [dostęp: 26.05.2015].

Roczna informacja statystyczna za rok 2006, Warszawa 2006, http://sw.gov.pl/Data/Files/kunickim/ statystyki/roczne/rok-2006.pdf [dostęp: 26.05.2015].

Roczna informacja statystyczna za rok 2007,Warszawa 2007, http://sw.gov.pl/Data/Files/kunickim/ statystyki/roczne/rok-2007.pdf [dostęp: 26.05.2015].

Roczna informacja statystyczna za rok 2008, Warszawa 2008, http://sw.gov.pl/Data/Files/kunickim/ statystyki/roczne/rok-2008.pdf [dostęp: 26.05.2015].

Roczna informacja statystyczna za rok 2009, Warszawa 2009, http://sw.gov.pl/Data/Files/kunickim/ statystyki/roczne/rok-2009.pdf [dostęp: 26.05.2015].

Roczna informacja statystyczna za rok 2010, Warszawa 2010, http://sw.gov.pl/Data/Files/_public/ rok-2010.pdf [dostęp: 26.05.2015].

Roczna informacja statystyczna za rok 2011, Warszawa 2011, http://sw.gov.pl/Data Files/001142rdeb/rok-2011.pdf [dostęp: 26.05.2015].

Roczna informacja statystyczna za rok 2012, Warszawa 2012, http://sw.gov.pl/Data/Files/001c169lidz/rok-2012.pdf [dostęp: 26.05.2015].

Roczna informacja statystyczna za rok 2014, Warszawa 2014, http://sw.gov.pl/Data/Files/001c169lidz/rok-2013.pdf [dostęp: 26.05.2015]. 
Roczna informacja statystyczna za rok 2014,Warszawa 2014, http://sw.gov.pl/Data/Files/001c169lidz/rok-2014.pdf [dostęp: 26.05.2015].

Sobolewska J., Siedza i czytaja, „Polityka” 2014, nr 33.

Szczupał B., Terapeutyczna funkcja biblioterapii w resocjalizacji i profilaktyce społecznej, [w:] Terapia $w$ resocjalizacji. Cz. I, ujęcie teoretyczne, red. A. Rejzner, P. Szczepaniak, Warszawa 2009.

Zarzadzenie 2/04 Dyrektora Generalnego Stużby Więziennej z dnia 24 lutego 2004 r., http://www. bip.sw.gov.pl/Dokumenty/zarzadzenie_2wsprawieszczego\%C5\%82owychzasadprowadzeniai organizacjipracy.pdf [dostęp: 30.05.2015].

Zybert E.B., Biblioteki więzienne, [w:] Encyklopedia książki, t. 1, red. A. Żbikowska-Migoń, M. Skalska-Zlat, Wrocław 2017.

Zybert E.B., Biblioteki więzienne: zarys problematyki, Warszawa 1991.

Zybert E.B., Wspótczesne biblioteki więzienne i działalność kulturalno-oświatowa w polskich zakładach stużby więziennej, „Przegląd Biblioteczny” 80, 2012, z. 1.

\section{Załączniki}

Tabela 1. Stosunek wieku skazanych do częstotliwości czytania

\begin{tabular}{|l|l|}
\hline \multicolumn{1}{|c|}{ Wiek } & Częstotliwość czytania \\
\hline 20 & co najmniej raz w miesiącu \\
\hline 22 & co najmniej raz w miesiącu \\
\hline 22 & co najmniej raz w miesiącu \\
\hline 23 & prawie codziennie \\
\hline 23 & codziennie \\
\hline 23 & raz na jakiś czas \\
\hline 24 & prawie codziennie \\
\hline 25 & prawie codziennie \\
\hline 25 & prawie codziennie \\
\hline 25 & co najmniej raz w miesiącu \\
\hline 26 & prawie codziennie \\
\hline 26 & prawie codziennie \\
\hline 26 & nie czyta \\
\hline 27 & co najmniej raz w miesiącu \\
\hline 27 & codziennie \\
\hline 28 & raz na jakiś czas \\
\hline 28 & prawie codziennie \\
\hline
\end{tabular}




\begin{tabular}{|c|c|}
\hline 28 & prawie codziennie \\
\hline 28 & nie czyta \\
\hline 29 & prawie codziennie \\
\hline 29 & codziennie \\
\hline 30 & co najmniej raz w miesiącu \\
\hline 31 & co najmniej raz w miesiącu \\
\hline 32 & prawie codziennie \\
\hline 32 & prawie codziennie \\
\hline 34 & co najmniej raz w miesiącu \\
\hline 34 & nie czyta \\
\hline 35 & raz na jakiś czas \\
\hline 35 & codziennie \\
\hline 35 & prawie codziennie \\
\hline 37 & co najmniej raz w miesiącu \\
\hline 37 & prawie codziennie \\
\hline 38 & codziennie \\
\hline 39 & co najmniej raz w miesiącu \\
\hline 39 & prawie codziennie \\
\hline 41 & co najmniej raz w miesiącu \\
\hline 42 & nie czyta \\
\hline 42 & prawie codziennie \\
\hline 43 & prawie codziennie \\
\hline 43 & codziennie \\
\hline 43 & codziennie \\
\hline 43 & codziennie \\
\hline 44 & codziennie \\
\hline 46 & codziennie \\
\hline 47 & co najmniej raz w miesiącu \\
\hline 48 & codziennie \\
\hline 52 & nie czyta \\
\hline 57 & co najmniej raz w miesiącu \\
\hline
\end{tabular}




\begin{tabular}{|l|l|}
\hline 60 & codziennie \\
\hline 65 & prawie codziennie \\
\hline
\end{tabular}

Tabela 2. Stosunek wykształcenia skazanych do częstotliwości czytania

\begin{tabular}{|l|l|}
\hline Wykształcenie & Częstotliwość czytania \\
\hline podstawowe niedokończone & co najmniej raz w miesiącu \\
\hline podstawowe & nie czyta \\
\hline podstawowe & co najmniej raz w miesiącu \\
\hline podstawowe & co najmniej raz w miesiącu \\
\hline podstawowe & co najmniej raz w miesiącu \\
\hline podstawowe & co najmniej raz w miesiącu \\
\hline podstawowe & prawie codziennie \\
\hline podstawowe & prawie codziennie \\
\hline podstawowe & prawie codziennie \\
\hline podstawowe & prawie codziennie \\
\hline podstawowe & prawie codziennie \\
\hline podstawowe & codziennie \\
\hline zasadnicze zawodowe & nie czyta \\
\hline zasadnicze zawodowe & nie czyta \\
\hline zasadnicze zawodowe & nie czyta \\
\hline zasadnicze zawodowe & raz na jakiś czas \\
\hline zasadnicze zawodowe & raz na jakiś czas \\
\hline zasadnicze zawodowe & raz na jakiś czas \\
\hline zasadnicze zawodowe & co najmniej raz w miesiącu \\
\hline zasadnicze zawodowe & co najmniej raz w miesiącu \\
\hline zasadnicze zawodowe & co najmniej raz w miesiącu \\
\hline zasadnicze zawodowe & co najmniej raz w miesiącu \\
\hline zasadnicze zawodowe & co najmniej raz w miesiącu \\
\hline zasadnicze zawodowe & pradniennie \\
\hline zasadnicze zawodowe & zawodowe \\
\hline
\end{tabular}




\begin{tabular}{|l|l|}
\hline zasadnicze zawodowe & prawie codziennie \\
\hline zasadnicze zawodowe & codziennie \\
\hline zasadnicze zawodowe & codziennie \\
\hline zasadnicze zawodowe & codziennie \\
\hline zasadnicze zawodowe & codziennie \\
\hline średnie bez matury & co najmniej raz w miesiącu \\
\hline średnie bez matury & prawie codziennie \\
\hline średnie bez matury & prawie codziennie \\
\hline średnie bez matury & prawie codziennie \\
\hline średnie bez matury & codziennie \\
\hline średnie z maturą & nie czyta \\
\hline średnie z maturą & co najmniej raz w miesiącu \\
\hline średnie z maturą & prawie codziennie \\
\hline średnie z maturą & prawie codziennie \\
\hline średnie z maturą & codziennie \\
\hline średnie z maturą & codziennie \\
\hline średnie z maturą & codziennie \\
\hline średnie z maturą & codziennie \\
\hline wyższe lub rozpoczęte studia & co najmniej raz w miesiącu \\
\hline wyższe lub rozpoczęte studia & prawie codziennie \\
\hline wyższe lub rozpoczęte studia & prawie codziennie \\
\hline wyższe lub rozpoczęte studia & prawie codziennie \\
\hline wyższe lub rozpoczęte studia & codziennie \\
\hline wyższe lub rozpoczęte studia & codziennie \\
\hline
\end{tabular}

Tabela 3. Stosunek wyroku otrzymanego przez skazanego do częstotliwości czytania

\begin{tabular}{|l|l|}
\hline Wyrok w latach & Częstotliwość czytania \\
\hline $3 \mathrm{~m}-1$ & nie czyta \\
\hline $3 \mathrm{~m}-1$ & co najmniej raz w miesiącu \\
\hline $3 \mathrm{~m}-1$ & codziennie \\
\hline $1-5$ & nie czyta \\
\hline
\end{tabular}




\begin{tabular}{|c|c|}
\hline $1-5$ & nie czyta \\
\hline $1-5$ & raz na jakiś czas \\
\hline $1-5$ & raz na jakiś czas \\
\hline $1-5$ & co najmniej raz w miesiącu \\
\hline $1-5$ & co najmniej raz w miesiącu \\
\hline $1-5$ & co najmniej raz w miesiącu \\
\hline $1-5$ & co najmniej raz w miesiącu \\
\hline $1-5$ & co najmniej raz w miesiącu \\
\hline $1-5$ & co najmniej raz w miesiącu \\
\hline $1-5$ & prawie codziennie \\
\hline $1-5$ & prawie codziennie \\
\hline $1-5$ & prawie codziennie \\
\hline $1-5$ & prawie codziennie \\
\hline $1-5$ & prawie codziennie \\
\hline $1-5$ & prawie codziennie \\
\hline $1-5$ & codziennie \\
\hline $1-5$ & codziennie \\
\hline $1-5$ & codziennie \\
\hline $1-5$ & codziennie \\
\hline $1-5$ & codziennie \\
\hline $1-5$ & codziennie \\
\hline $1-5$ & codziennie \\
\hline $2-12$ & codziennie \\
\hline $2-12$ & codziennie \\
\hline $5-15$ & raz na jakiś czas \\
\hline $5-15$ & co najmniej raz w miesiącu \\
\hline $5-15$ & co najmniej raz w miesiącu \\
\hline $5-15$ & co najmniej raz w miesiącu \\
\hline $5-15$ & co najmniej raz w miesiącu \\
\hline $5-15$ & co najmniej raz w miesiącu \\
\hline $5-15$ & co najmniej raz $\mathrm{w}$ miesiącu \\
\hline
\end{tabular}




\begin{tabular}{|l|l|}
\hline $5-15$ & prawie codziennie \\
\hline $5-15$ & prawie codziennie \\
\hline $5-15$ & prawie codziennie \\
\hline $5-15$ & prawie codziennie \\
\hline $5-15$ & prawie codziennie \\
\hline $5-15$ & prawie codziennie \\
\hline $5-15$ & prawie codziennie \\
\hline $5-15$ & prawie codziennie \\
\hline $5-15$ & prawie codziennie \\
\hline $5-15$ & prawie codziennie \\
\hline $5-15$ & codziennie \\
\hline $5-15$ & codziennie \\
\hline 25 & nie czyta \\
\hline 25 & prawie codziennie \\
\hline dożywocie & nie czyta \\
\hline
\end{tabular}

Tabela 4. Stosunek czasu spędzonego przez skazanego w więzieniu do częstotliwości czytania

\begin{tabular}{|l|l|}
\hline \multicolumn{1}{|c|}{$\begin{array}{c}\text { Czas } \\
\text { w więzieniu } \\
\text { wiesiącach }\end{array}$} & Częstotliwość czytania \\
\hline 1 & nie czyta \\
\hline 2 & raz na jakiś czas \\
\hline 2 & prawie codziennie \\
\hline 2 & codziennie \\
\hline 4 & co najmniej raz w miesiącu \\
\hline 4 & co najmniej raz w miesiącu \\
\hline 5 & prawie codziennie \\
\hline 6 & nie czyta \\
\hline 6 & prawie codziennie \\
\hline 8 & prawie codziennie \\
\hline 10 & co najmniej raz w miesiącu \\
\hline 12 & prawie codziennie \\
\hline
\end{tabular}




\begin{tabular}{|c|c|}
\hline 14 & co najmniej raz w miesiącu \\
\hline 16 & co najmniej raz w miesiącu \\
\hline 16 & prawie codziennie \\
\hline 23 & codziennie \\
\hline 23 & codziennie \\
\hline 24 & raz na jakiś czas \\
\hline 25 & nie czyta \\
\hline 25 & co najmniej raz w miesiącu \\
\hline 28 & codziennie \\
\hline 30 & co najmniej raz w miesiącu \\
\hline 30 & co najmniej raz w miesiącu \\
\hline 33 & co najmniej raz w miesiącu \\
\hline 36 & prawie codziennie \\
\hline 36 & prawie codziennie \\
\hline 38 & codziennie \\
\hline 45 & prawie codziennie \\
\hline 48 & co najmniej raz w miesiącu \\
\hline 48 & prawie codziennie \\
\hline 48 & codziennie \\
\hline 48 & codziennie \\
\hline 48 & codziennie \\
\hline 48 & codziennie \\
\hline 54 & codziennie \\
\hline 54 & codziennie \\
\hline 60 & prawie codziennie \\
\hline 60 & prawie codziennie \\
\hline 60 & prawie codziennie \\
\hline 66 & co najmniej raz w miesiącu \\
\hline 66 & codziennie \\
\hline 69 & co najmniej raz w miesiącu \\
\hline 72 & nie czyta \\
\hline
\end{tabular}




\begin{tabular}{|l|l|}
\hline 78 & prawie codziennie \\
\hline 96 & prawie codziennie \\
\hline 120 & raz na jakiś czas \\
\hline 120 & co najmniej raz w miesiącu \\
\hline 120 & prawie codziennie \\
\hline 132 & prawie codziennie \\
\hline 180 & nie czyta \\
\hline
\end{tabular}

\title{
Readership of prisoners in the Rawicz prison
}

\begin{abstract}
Summary
A prison library is an institution intended to provide convicts with access to literature, culture, and education. In Poland, the approach to functions of prisons and prison libraries changed with political system transformation. After 1989 the penology was modified from the repressive model to the rehabilitative one. Prisoners can participate in cultural events, such as theatre performances, book clubs and prison newspapers publishing. Such involvement should be based on well-equipped library supervised by a qualified librarian. The reality is different, but statistics of Central Statistical Office of Poland (GUS) reveal that prison libraries in Poland are constantly developing. The author of the work conducted the survey in the prison in Rawicz aimed at the exploration of prisoners' readership. The analysis involved 50 individuals. According to the study's results, convicts consider the library as a necessary institution, which they use willingly. Most of the respondents admitted that they read books, while almost all of them reported reading the press. The most popular literary genres among the surveyed turned out to be fantastic and detective stories.
\end{abstract}

KEYWORDS: prison's library, prisoner's reading, resocialization 